\title{
Uji Efek Antihiperlipidemia Ekstrak Etanol Batang Tumbuhan Bambu-bambu (Polygonum pulchrum Blume) pada Mencit Jantan Galur Balb-C
}

\author{
Wahyuni, Sahidin ${ }^{1}$, Muhammad Rustam HN², Muhammad Hajrul Malaka ${ }^{1}$, Muhammad Ilyas \\ Yusuf ${ }^{1,3}$, Feny R. Poko ${ }^{1}$
}

${ }^{1}$ Fakultas Farmasi Universitas Halu Oleo, Kampus Hijau Bumi Tridharma Anduonohu Kendari 93232

${ }^{2}$ Fakultas Kedokteran Universitas Halu Oleo, Kampus Hijau Bumi Tridharma Anduonohu Kendari 93232

${ }^{3}$ Akademi Analis Kesehatan Bina Husada Kendari, Jl. Sorumba no. 17 Kendari, 93117

E-mail: wahyuni@uho.ac.id

\begin{abstract}
Abstrak
Hiperlipidemia adalah penyakit kelainan metabolisme lipid yang ditandai dengan adanya peningkatan kadar kolesterol total, LDL (Low Density Lipoprotein), trigliserida, dan penurunan kadar HDL (High Density Lipoprotein) di dalam darah, serta penyebab terjadinya aterosklerosis dan penyakit jantung koroner. Penelitian ini bertujuan untuk mengetahui efek antihiperlipidemia dari ekstrak etanol batang tanaman bambu-bambu (Polygonum pulchrum Blume) pada mencit jantan galur Balb-C. Sebanyak 42 ekor mencit jantan galur Balb-C dibagi secara acak ke dalam enam kelompok yaitu kelompok kontrol normal, kelompok kontrol induksi MDLT, kelompok kontrol dosis I, dosis II, dosis III dan kelompok pembanding (simvastatin). Kelompok kontrol normal hanya diberikan makanan standar (pellet). Kelompok kontrol induksi MDLT, dosis I, dosis II, dosis III, dan pembanding (simvastatin) diberikan Makanan Diet Lemak Tinggi (kuning telur 80\%, sukrosa 15\%, lemak sapi 5\% dan PTU $25 \mathrm{mg} / \mathrm{ml}$ ). Setelah 2 minggu pemberian, ditambahkan berturut-turut Na-CMC 0,5\% ekstrak dengan dosis 1,36 mg/gBB, 4,09 mg/gBB, 7,28 mg/gBB, dan simvastatin $0,1 \mathrm{mg} / \mathrm{gBB}$ pada kelompok kontrol dosis I, dosis II, dosis III dan kelompok pembanding (simvastatin). Setelah $1 \mathrm{minggu}$ perlakuan, dilakukan pengambilan darah pada vena aorta dan penetapan kadar kolesterol total, kadar trigliserida, kadar HDL dan kadar LDL. Hasil penelitian menunjukkan bahwa ekstrak etanol batang tanaman bambu-bambu (Polygonum pulchrum Blume) memiliki efek antihiperlipidemia pada dosis $4,09 \mathrm{mg} / \mathrm{gBB}$ ditinjau dari penurunan kadar kolesterol total, kadar trigliserida, peningkatan kadar HDL dan dosis III 7,28 mg/gBB ditinjau dari penurunan kadar LDL.
\end{abstract}

Kata kunci: bambu-bambu, Polygonum, HDL, LDL, hiperlipidemia, fitosterol

\section{Pendahuluan}

Hiperlipidemia adalah suatu penyakit atau kelainan metabolisme lipid yang ditandai dengan adanya peningkatan kadar kolesterol total, LDL (Low Density Lipoprotein), trigliserida, dan penurunan kadar HDL (High Density Lipoprotein) di dalam serum darah [1]. Hiperlipidemia merupakan salah satu faktor resiko timbulnya penyakit jantung koroner yang disebabkan oleh aterosklerosis dan merupakan penyakit yang paling banyak menyebabkan kematian utama di Negara yang telah maju dan termasuk negara Indonesia [8].

Aterosklerosis adalah suatu penyakit yang ditandai dengan penebalan dan hilangnya elastisitas dinding arteri yang ditandai dengan terdapatnya plak ateroma pada bagian inti arteri yang berisi kolesterol, zat lipoid, dan lipofag [8] yang disebabkan karena disfungsi endotel dan kadar kolesterol (LDL) yang tinggi dikarenakan kadar LDL mudah mengalami oksidasi oleh radikal bebas [5].

Salah satu obat tradisional yang sering digunakan masyarakat berasal dari tumbuhan genus Polygonum. Genus Polygonum terdiri dari 150 - 300 spesies tumbuhan yang berbeda-beda yang tersebar luas di seluruh dunia [2,
7]. Tumbuhan dari genus Polygonum secara etnobotani memiliki aplikasi yang cukup luas di masyarakat dalam pengobatan berbagai penyakit. Menurut Dong dkk. (2014) genus Polygonum memiliki beragam efek farmakologi, misalnya sebagai antioksidan ( $P$. amplexicaule), antiinflammatory ( $P$. cuspidatum), antibakteri-antijamur $(P$. bistorta), antikanker ( $P$. hypoleucum), dan antiviral (P.tinctorium) [2]. Tanaman bambu-bambu (Polygonum pulchrum Blume) mengandung senyawa fitosterol dan diketahui memiliki aktivitas antioksidan pada bagian batang tanaman [7].

\section{Bahan dan Metode}

\subsection{Hewan Uji}

Hewan uji yang digunakan dalam penelitian ini adalah mencit jantan (Mus musculus) galur Balb-C berat badan 2530 g. Sebelum penelitian dilakukan mencit diaklimatisasi selama tujuh hari untuk membiasakan pada lingkungan percobaan, dan diberi makanan standar. Hewan dianggap 
sehat apabila perubahan berat badan tidak lebih dari $10 \%$ serta memperlihatkan perilaku normal.

\subsection{Ekstraksi}

Sampel batang tumbuhan bambu-bambu sebanyak 5 kg yang telah dikumpulkan dan dicuci bersih, lalu ditiriskan untuk menghilangkan sisa air, kemudian dikeringkan dengan cara diangin-anginkan di udara terbuka. Sampel diserbukkan, kemudian penyarian dilakukan dengan metode maserasi dengan pelarut etanol sampai semua sampel terendam. Setiap 1x24 jam dilakukan pengadukan pada sampel. Kemudian dilakukan pemisahan residu dan filtrat setelah 3x24 jam. Filtrat dikumpulkan dan dipekatkan dengan rotary vacuum evaporator pada suhu $50^{\circ} \mathrm{C}$ hingga diperoleh ekstrak etanol kental.

\subsection{Skrining Fitokimia}

Uji penapisan fitokimia dilakukan untuk mengetahui apakah ekstrak etanol batang tumbuhan bambu-bambu memenuhi syarat yang sesuai dengan ketentuan yang ditetapkan dalam monografi.

\subsection{Uji Efek Antihiperlipidemia}

Makanan Diet LemakTinggi (MDLT) yang diberikan pada hewan uji terdiri dari campuran lemak sapi, kuning telur, sukrosa, dan PTU yang dibuat dalam bentuk emulsi.MDLT diberikan secara oral selama 14 hari untuk meningkatkan kadar kolesterol total, trigliserida, LDL dan untuk menurunkan kadar HDL. Selama tujuh hari (satu kali sehari) diberikan ekstrak etanol tumbuhan bambu-bambu dengan tiga varian dosis yaitu $1,36 \mathrm{mg} / \mathrm{gBB}, 4,09 \mathrm{mg} / \mathrm{gBB}$, $7,28 \mathrm{mg} / \mathrm{gBB}$. Hewan coba dibagi dalam 6 kelompok, yaitu kelompok kontrol normal, kontrol induksi MDLT, kelompok pembanding (simvastatin) dan kelompok uji dosis I, dosis II, dosis III. Pengambilan plasma darah menggunakan reagen kit kolesterol total, reagen kit trigliserida, dan reagen kit HDL sedangkan pengukuran kadar LDL menggunakan rumus MC Pherson and Pinus

$$
L D L \mathrm{mg} / \mathrm{dl}=\text { Kolesterol total }-\frac{\text { Trigliserida }}{6,5}
$$

\subsection{Analisis Data}

Analisis data yang digunakan dalam penelitian ini menggunakan metode One-way Analysis of Variance (ANOVA) dengan perangkat lunak Statistical Package For Social Science (SPSS) versi 19, dengan taraf kepercayaan
95\% untuk menganalisis kadar kolesterol total, kadar trigliserida, kadar HDL dan kadar LDL dengan variasi dosis ekstrak untuk masing-masing perlakuan

\section{Hasil dan Pembahasan}

Penapisan fitokimia bertujuan untuk mengetahui senyawa metabolit sekunder yang terkandung dalam ekstrak yang berkaitan dengan khasiat dan aktivitas farmakologinya [3]. Hasil Hasil skrining fitokimia melalui uji KLT menunjukkan ekstral etanol batang tumbuhan bambu-bambu mengandung flavanoid, alkaloid, fenol, saponin, kuinon dan fitosterol. Hasil perhitungan rendemen, pengujian kadar sari larut air dan kadar sari larut etanol berturut-turut yaitu $6,43 \%, 15,99 \%$, dan $32 \%$. Dengan demikian, pelarut etanol yang digunakan sesuai untuk mengekstraksi batang tanaman bambu-bambu.

Pemberian ekstrak etanol batang tanaman bambubambu (Polygonum pulchrum Blume) dengan tiga varian dosis dan pemberian simvastatin mampu menurunkan kadar kolesterol total, kadar trigliserida, kadar LDL dan mampu meningkatkan kadar HDL pada darah mencit hiperlipidemia. Penurunan kadar kolesterol tersebut dikarenakan adanya senyawa flavonoid dan senyawa fitosterol. Senyawa flavonoid dapat menurunkan kadar kolesterol di dalam darah dengan cara menaikkan densitas reseptor LDL di liver, mengikat apolipoprotein B, mereduksi trigliserida (TG) dan meningkatkan HDL serta menurunkan kadar kolesterol dalam darah dengan cara menghambat kerja enzim 3-hidroksi 3-metilglutaril koenzim A reduktase [4].

Senyawa fitosterol dalam hal ini yaitu stigmasterol mampu menurunkan kadar kolesterol total, kadar trigliserida, kadar LDL dan meningkatkan kadar HDL pada darah mencit hiperlipidemia dengan cara menghambat penyerapan kolesterol di usus melalui kompetisi dengan kolesterol pada proses penyerapannya di dalam usus, sehingga membantu menurunkan jumlah kolesterol yang memasuki aliran darah serta mempercepat ekskresi kolesterol [6]. Penghambatan penyerapan kolesterol terjadi karena proses absorbsi fitosterol sangat rendah. Menurunnya kadar kolesterol yang memasuki aliran darah akan memperkecil kemungkinan terjadinya penumpukan lemak di organ tubuh dan memperkecil terjadinya obesitas. Selain menghambat penyerapan dan mempercepat ekskresi kolesterol, fitosterol berfungsi dalam memperbaiki regulasi kolesterol darah pada tingkat yang normal.

Simvastatin bekerja dengan cara menghambat kerja enzim 3-hidroksi 3-metilglutaril koenzim A reduktase (HMG Co-A reduktase). Enzim ini mengkatalisis perubahan HMG Co-A menjadi asam mevalonat yang

Tabel 1. Kadar rata-rata kolesterol total, trigliserida, HDL, LDL mencit hiperlipidemia

\begin{tabular}{|c|c|c|c|c|c|}
\hline \multirow{2}{*}{ No } & \multirow{2}{*}{ Kelompok } & \multicolumn{4}{|c|}{ Kadar rata-rata $(\mathrm{mg} / \mathrm{dl}) \pm \mathrm{SD}$} \\
\hline & & Kolesterol total & Trigliserida & HDL & LDL \\
\hline 1 & Kontrol normal & $45.14 \pm 12.15$ & $131 \pm 11.59$ & $71,71 \pm 2,21$ & $46,72 \pm 13,45$ \\
\hline 2 & Kontrol induksi MDLT & $106.14 \pm 9.40$ & $166.85 \pm 6.28$ & $21,42 \pm 0,97$ & $59,04 \pm 9,67$ \\
\hline 3 & Kontrol dosis I & $51.71 \pm 18.10$ & $165.42 \pm 10.24$ & $76 \pm 1.15$ & $49,73 \pm 16,61$ \\
\hline 4 & Kontrol dosis II & $56.57 \pm 7.52$ & $122.14 \pm 4.09$ & $75,28 \pm 1,11$ & $37,50 \pm 8,40$ \\
\hline 5 & Kontrol dosis III & $85.28 \pm 9.75$ & $136.42 \pm 8.14$ & $72,14 \pm 2,19$ & $10,26 \pm 7,89$ \\
\hline 6 & Kontrol pembanding & $68.14 \pm 13.80$ & $146.28 \pm 12.13$ & $78,71 \pm 2.62$ & $33,07 \pm 13,99$ \\
\hline
\end{tabular}


merupakan langkah awal dari sintesa kolesterol yang menyebabkan peningkatan kadar kolesterol total, kadar LDL, kadar trigliserida dan penurunan kadar HDL $[4,6]$. Hasil uji statistik One Way ANOVA (uji normalitas dan uji homogenitas) serta uji post hoc LSD menunjukkan bahwa dosis II 4,09 mg/gBB efektif dalam menurunkan kadar kolesterol total, kadar trigliserida, kadar LDL dan mampu meningkatkan kadar HDL dan mampu menggantikan obat simvastatin sebagai antihiperlipidemia dengan nilai $\mathrm{p}<0,05$.

\section{Kesimpulan}

Pemberian ekstrak etanol batang tanaman bambubambu (Polygonum pulchrum Blume) pada dosis 4,09 $\mathrm{mg} / \mathrm{kgBB}$ efektif dalam menurunkan kadar kolesterol total, kadar trigliserida, dan meningkatkan kadar HDL.

\section{Ucapan Terima Kasih}

Ucapan terima kasih kepada Fakultas Farmasi Universitas Halu Oleo atas dukungan dan bantuan dalam pelaksanaan penelitian ini.

\section{Daftar Pustaka}

1. Choudary GP. Hypocholesterolemic Effect of Ethanolic Extract of Fruits of Terminalia Chebula in High Fat Diet Fed
Foster Rats. Int J Journal of Adv in Pharm Bio Chem, 2013, 2(1);13-15.

2. Dong X, Fu J, Yin X, Li X, Wang B, Cao S, Zhang J, Zhang H, Zhao Y, Ni J. Pharmacological and other Bioactivities of the Genus Polygonum - A Review, Tropical Journal of Pharmaceutical, 2014, 13(10);1749-1759.

3. Harborne JB. Metode Fitokimia: Penuntun Cara Modern Menganalisis Tumbuhan. (diterjemahkan oleh Kosasih Padmawinata dan Iwang Soediro). Bandung: Penerbit ITB, 1987.

4. McPherson RA, Pincus MR. Henry's Clinical Diagnosis and Management by Laboratory Method, (Ed-21), New York: Elsevier Ltd., 2001.

5. Milioti N, Fajardo AB, Penichet ML, Orta EO. AntigenInduced Immunomodulation in the Pathogenesis of Atherosclerosis, Hindawi Publishing Corporation Clinical and Developmental Immunology, 20018; 1-15.

6. Prahastuti S, Susy T, Entin H. The Effect of Bay Leaf Infusion (Syzygium polyanthum (Wight) Walp) to Decrease Blood Total Cholesterol Level in Dyslipidemia Model Wistar Rats, Jurnal Medika Planta, 2011, 1 (4).

7. Sahidin, Nohong, Sani, A., Manggau, M.A.,Sukohar, A., Widodo, H., Baharum, S., 2014, Radical Scavenging Activity of Triterpene Steroids From Stem Ofpolygonum Pulchrum B1, International Journal of Pharmacy and Pharmaceutical Sciences, 6(8), 350-354.

8. Setiabudy R, Nafrialdi. Farmakologi dan Terapi, Edisi 5, Jakarta: Balai Penerbit FKUI, 2007. 